Article

\title{
Formative Transcendence of Flipped Learning in Mathematics Students of Secondary Education
}

\author{
Jesús López Belmonte ${ }^{\mathbb{D}}$, Arturo Fuentes Cabrera, Juan Antonio López Núñez ${ }^{\mathbb{D}}$ and \\ Santiago Pozo Sánchez *iD \\ Department of Didactics and School Organization, University of Granada, 18071 Granada, Spain; \\ jesuslopez@ugr.es (J.L.B.); arturofuentes@ugr.es (A.F.C.); juanlope@ugr.es (J.A.L.N.) \\ * Correspondence: santiagopozo@correo.ugr.es
}

Received: 2 November 2019; Accepted: 10 December 2019; Published: 12 December 2019

\begin{abstract}
Educational technology is achieving great potential in the formative processes of today's society. Flipped learning is considered as a pedagogical innovation derived from the technological influence in learning spaces. The general objective of the research is to analyze the effectiveness of flipped learning on a traditional teaching and learning approach in the subject of Mathematics. To achieve this objective, an experimental design of a descriptive and correlational type has been followed through a quantitative research method. Two study groups have been set up. In the control group, the contents have been imparted from a traditional perspective, and in the experimental group, innovation has been applied through the use of flipped learning. The sample of participants has been chosen by means of intentional sampling and reached the figure of 60 students in the 4th year of Secondary Education at an educational center in Ceuta (Spain). A questionnaire has been used for data collection. The results reflect that the application of flipped learning has obtained better assessment in established attitudinal and mathematical indicators. It is concluded that with the use of flipped learning, motivation and skills are increased in the analysis and representation of graphs.
\end{abstract}

Keywords: ICT; educational innovation; digital learning; mixed learning; experimentation; methodological contrast; learning impact; didactic benefits; secondary education

\section{Introduction}

Today, teaching is witnessing a period of transformation motivated by technological inclusion. This transformation has materialized at all levels and areas [1,2]. Consequently, the appearance of new ways of teaching [3] and new means of learning in students [4] have been encouraged in teachers. However, this transformation is often too slow, causing the educational action that takes place in the classroom to not be adapted to the context in which it develops. This is caused by the non-appearance of innovative actions, which require the use of new methodologies and the implementation of new pedagogical tendencies that allow for the reversal of the spaces, times, and actions of traditional education [5].

At the forefront of innovative pedagogical trends is flipped learning [6]. This instructional methodology is characterized by being an alternative in educational practice, where the use of information and communication technology (ICT) [7] stands out, investing in the roles of the learning process and giving leadership to students [8,9]. A relevant aspect is the importance that this innovative approach has assumed in the brief temporal space it has in the field of education [10,11].

Flipped learning is the result of the work of two specialists in the field such as Aaron Sams and Jonathan Bergmann, who in 2012, were able to develop online audiovisual teaching material so that students who could not attend classrooms regularly could still participate regardless of factors such as place and time [12]. The evolution of this pedagogical trend has been remarkable [13]. In this sense, 
flipped learning has many followers around the world. This methodology is carried out by thousands of teachers in their classrooms and has obtained the confidence of many pedagogues for its effectiveness in the development of educational processes and for the achievement of objectives [14-16].

At the educational level, flipped learning is considered a mixed process that involves both online teaching and face-to-face teaching [17]. This involves an exchange of roles between educational agents. The teacher goes from being the protagonist to being in charge of guiding and guiding the student's instructional process through both face-to-face and virtual tutoring of the students, and also becomes the creator of audiovisual teaching materials $[18,19]$. This methodology requires turning around the daily didactic processes to which we are accustomed, that is, with flipped learning, the student visualizes and assimilates the contents in their home or in any place and medium that allows them to access audiovisual resources before going to school [20]. Therefore, students acquire content knowledge through instructional materials prepared by teachers through multimedia resources (i.e., videos, simulations, activities, online lectures) provided on a digital platform [21]. This technology platform and online learning environment in flipped instruction allows students the affordance of additional time and space to practice, deepen content knowledge, and apply problem solving beyond the face-to-face in-class learning environment [22-25].

This technopedagogical approach focuses its main action on reversing the spatiotemporal factor and the way in which the educational action takes place $[26,27]$. On the one hand, the face-to-face teaching period is invested in performing participatory practices and dynamics of collective work that relate to the theory that has previously worked for students into virtual environments [28,29]. This means a greater use of the face-to-face session [30] and greater interaction and collaboration between all the agents involved in the instructional process [31-33]. This results in greater student participation [34] and in better resolution of problems [35,36]. In addition, it gives the main role of all learning to the student, becoming the leading figure of all educational action. This promotes their autonomy, planning, and decision-making about their instructional period [37,38].

This innovative methodology makes it easier for students to access the contents of the subject that is the object of study from any device with internet access [39]. This promotes individualized learning adapted to the needs of each student. With flipped learning, educational support actions are promoted at any time the student requires. Students can access the digital platform and visualize audiovisual materials infinitely until the contents are assimilated [7]. This encourages learning facilitated by technology that has an effect on increasing motivation. Not only does ICT enhance motivation, they also produce the new active role of protagonist for the student, and the change in the daily routine of the student, who is no longer a simple receiver of information, increases the available time for practical tasks, collaboration, and teamwork to solve problems in the classroom [40,41]. All these described benefits and actions for the condition for results of the grades obtained by students that are increased with this innovative methodology due to all the previous work that was done [42,43].

Flipped learning has become a fundamental approach for the development of good teaching action based on the technopedagogical use of ICT [44]. This innovation takes into account the characteristics of current education [45], and thanks to its formative investment with respect to traditional approaches [46], it manages to generate unique and innovative experiences for its own learning of the digital era [47]. All this improves the search and achievement of quality indicators in the instructional action [48]. Therefore, the effect caused by flipped learning in the various academic indicators is superior to that achieved by traditional methods $[49,50]$.

This study focuses on the optimization of learning in Mathematics, an area of knowledge in which the inclusion of innovative practices is essential. The formative success lies in using innovation as a starting point for new educational experiences with Mathematics, that is, redefining the way of teaching and learning [51]. ICT assists students in learning Mathematics in a more effective way, by improving certain aspects such as understanding, autonomy, meaningful learning, and the acquisition of skills [52].

Studies carried out to date on the state of the matter show that teachers who have been able to implement flipped learning in their teaching practice in Mathematics have obtained high indicators of 
success in students, especially with regard to motivation [53,54]. The literature states that it is more effective to learn mathematics through multimedia content than through traditional practices $[55,56]$. Similarly, it has been reported that students have a better attitude and better performance with this innovative methodology [57], better self-regulation and learning achievements [58], a greater use of session time [59], greater collaboration with other students [60], and relevant adaptation to their individual needs [61]. In short, all this entails an improvement in student participation, performance, and grades [62-64].

The literature reveals studies that promote the teaching and learning of Mathematics through new technologies in order to facilitate the innovation process in an ancestral subject. In addition, it has been reported that the application of ICT in Mathematics has already been carried out at different levels and educational stages $[65,66]$.

Studies similar to the one presented in this work used flipped learning in Mathematics to analyze their effectiveness, finding relevant improvements in the teaching and learning process [61,67-69].

However, in the present study, other variables have also been considered that have not been studied specifically in previous research in order to fill the existing literary gap in the learning of mathematics contents through technopedagogical approaches. Therefore, this research reaches an exploratory component to try to solve the literary deficiencies in this field of knowledge.

Justification and Research Questions

The technological peculiarities of contemporary society entail an update and renewal of the teaching practice carried out in the learning spaces [2]. Specifically, the Mathematics subject -due to its nature and long career throughout the history of education- demands innovative pedagogical action with the purpose of improving academic indicators related to the subject itself and the attitude of the students $[70,71]$.

Based on these requirements, in this study, an experiment was developed through the use of the flipped learning methodological approach during the daily course of Mathematics classes. This innovative implementation aims to adapt the teaching and learning processes to the new challenges, resources, and teaching tools that have emerged as a result of the technological boom [72].

Two prominent premises in the use of flipped learning linked to the effectiveness of the instructional process are the characteristics of the students [18] and their educational stage [73], which will largely determine the results achieved.

The present study intends to confirm the effectiveness that flipped learning has obtained in the field of educational research as reported in the recent impact literature $[7,11,13,49,50,73-75]$. This effectiveness has been contrasted with the classical and expository methods of knowledge transmission, where the teacher reproduces the contents unilaterally without encouraging the exchange of knowledge and interaction with students [76].

The experimentation has been carried out at the last level of the Secondary Education stage, justified in the great use and familiarization that students have at that age [77] in such a way that there is error bias in the management of resources and technological means.

For all the above, the main problem of this research is to know if flipped learning is effective in Mathematics compared to the performance of a traditional praxis in Secondary Education. Following this problem, the following research questions (RQ) are established:

- RQ1: Does the instructional modality include motivation, autonomy, collaboration, participation, problem solving, and class time?

- $\mathrm{RQ}_{2}$ : Does the instructional modality in the knowledge of scientific language and mathematical concepts?

- $\quad \mathrm{RQ}_{3}$ : Does the instructional modality affect the use of data and scientific processes?

- $\mathrm{RQ}_{4}$ : Does the instructional modality in the analysis and representation of graphs?

- $\mathrm{RQ}_{5}$ : Does the instructional modality affect the interpretation and reflection of results?

- $\mathrm{RQ}_{6}$ : Does the instructional modality affect the decision-making process of the students? 
- $\mathrm{RQ}_{7}$ : Does the instructional modality include the qualification obtained in the evaluation tests?

\section{Materials and Methods}

\subsection{Research Design and Data Analysis}

The research process was carried out through an experimental design of a descriptive and correlational type from a quantitative perspective according to the indications of the experts [78,79]. It has delimited two groups of analysis in the experimentation. On the one hand, the control group that has followed a traditional methodology and, on the other, the experimental group that has used flipped learning to deliver the contents. This defines, as an independent variable, the type of methodology, and as a dependent variable, the effectiveness obtained in the different indicators to be evaluated.

Statistical treatment has been carried out with the Statistical Package for the Social Sciences (SPSS) v24 program. In the data analysis, basic statistics such as the mean (M) and standard deviation (SD) have been used. The Fisher's skewness (Skew) and Pearson's kurtosis (Kurt) has been used to determine the distribution trend of the collected data. The comparison of means between the study groups was carried out using Student's t-test, and the measurement of the size of the effect caused was obtained by Cohen's $d$ and the biserial correlation $(r)$. Likewise, $p<0.05$ has been established as a statistically significant difference.

\subsection{Participants}

A total of 60 secondary school students participated in the study. In impact studies, it has been shown that the sample size in this type of research does not precondition the performance of these experiments [80,81].

The students have been chosen through an intentional sampling carried out in an educational center of the Autonomous City of Ceuta (Spain), justified in the easy access to the students. This specific contextualization with its social, geographical, and multicultural characteristics $[82,83]$ allows obtaining new results compared to previous research on the state of the matter.

Specifically, the sample of students is selected from the 4th year of Secondary Education $(n=60$; $\mathrm{M}_{\mathrm{AGE}}=16$ years; $\mathrm{SD}=1.34$ ). The configuration of the control and experimental groups is established in Table 1.

Table 1. Study groups by sex.

\begin{tabular}{cccc}
\hline Study Groups & $\begin{array}{c}\text { Boys } \\
\boldsymbol{n} \mathbf{( \% )}\end{array}$ & $\begin{array}{c}\text { Girls } \\
\boldsymbol{n ( \% )}\end{array}$ & $\begin{array}{c}\text { Total } \\
\boldsymbol{n}(\mathbf{\%})\end{array}$ \\
\hline Experimental group & $13(43.33)$ & $17(56.67)$ & $30(50)$ \\
Control group & $11(36.67)$ & $19(63.33)$ & $30(50)$ \\
Subtotal & $24(40)$ & $36(60)$ & $60(100)$ \\
\hline \multicolumn{4}{c}{ Source: Own elaboration. }
\end{tabular}

\subsection{Instrument}

An ad hoc questionnaire has been the instrument used in the data collection process. This tool has been designed following other validated instruments obtained from the scientific literature $[73,84,85]$. The prepared questionnaire presents 42 items (see Table S1). These questions are divided between the Socioeducational, Attitudinal, and Mathematical dimensions. In the configuration of the items, a Likert scale has been followed with a range of four points (from $1=$ None to $4=$ Completely).

The validation process of the generated instrument has been carried out at a qualitative and quantitative level. First, a Delphi method for qualitative validity has been carried out. This technique has involved 10 experts in educational technology in the field of mathematics at various universities. The assessment of the questionnaire by these specialists was positive $(\mathrm{M}=4.87 ; \mathrm{SD}=0.21$; $\min =1$; 
max $=6$ ). In addition, experts developed recommendations to improve the optimization of the instrument:

- Unify certain items to reduce their volume.

- Improve the writing of some issues.

- Establish new items proposed to favor the measurement of some variables.

In this feedback, the Kappa of Fleiss and W of Kendall were applied to obtain the indices of concordance and relevance of the observations given, whose results were adequate $(K=0.85 ; \mathrm{W}=0.84)$. Next, quantitative validation was initiated by an exploratory factor analysis by the principal component method with varimax rotation. In the tests performed, dependence between the delimited variables was determined (Bartlett's test of sphericity $=2538.17 ; p<0.001$ ) and a relevant adequacy of the sample (Kaiser-Meyer-Olkin $=0.86$ ).

In addition, other statistics were used to measure the reliability of the questionnaire such as Cronbach's alpha $(\alpha)(0.88)$, compound reliability $(0.86)$, and mean variance extracted $(0.83)$, reaching values that confirm the reliability of the developed instrument.

\subsection{Procedure}

The research has been developed in different phases. First, there was the design and validation of the questionnaire to measure the different established variables. Then, the study participants were chosen through the collaboration and proximity of the researchers with the Mathematics Department of the educational center. Next, the students were randomly grouped into the two analysis groups. Due to the characteristics of the educational center that has two groups (A-B) at each level, a raffle was held to determine what the control and the experimental one was going to be. The result configured group A as a control and group B as experimental. To develop the experimentation, the teacher (a researcher of this study who teaches at the school) gave a teaching unit (12 sessions) to both groups but through two different methodologies (control group = traditional; experimental group = flipped learning).

The traditional pedagogical intervention was based on the teaching of the contents in an expository manner by the teacher and without using technological resources. Specifically, the function of the teacher was to impart the contents as the only resource for knowledge, using the conventional blackboard and chalk to perform exercises. The students' role was limited only to paying attention to the teacher's explanations, so there were interactions with the contents, and the interactions with the classmates and with the teacher were practically non-existent. Once the contents programmed for each session were explained, the students carried out individual tasks in class in their notebook to practice the contents explained by the teacher.

The innovative intervention that was carried out with flipped learning was a situational investment based on the visualization of previous audiovisual resources to promote an improvement in the acquisition of the contents in the classroom $[22,24,25]$. The students visualized the contents in audiovisual devices, outside the school environment, with the intention of starting the classroom with a better assimilation of the planned contents. This encouraged the use of ICT, the flipping of learning moments, and the ubiquity of the training process. With this innovative practice, the teacher devoted more time to the realization of practical exercises, resolution of doubts, and deepening of the contents because the explanation of the contents had happened outside the classroom. In addition, students continued to visualize audiovisual resources in the classroom through tablets to facilitate individualized learning adapted to the characteristics of each student. In this way, the teacher was able to devote more time and more dedication to those students who had greater difficulties in acquiring the contents.

The didactic contents taught were related to statistics, graphic representations, and problem solving. In this way, in the different sessions, the following didactic objectives were worked through: (a) to know the scientific language and concepts of statistics (sessions 1-2); (b) to understand the fundamental principles for data processing and scientific processes (sessions 3-4); (c) to acquire skills in statistical 
analysis and representation of graphs (sessions 5-8); (d) to assimilate skills in the interpretation and reflection of results (sessions 7-10); and (e) to develop skills for correct decision-making (sessions 11-12).

Finally, the data collection of the students was carried out using the questionnaire described above. The data obtained were analyzed in depth at the statistical level in order to answer the established research questions.

\section{Results}

\subsection{Descriptive Analysis of the Effect of the Traditional Formative Modality on the Attitudinal and Mathematical Dimension}

First, the results in Table 2 contain the scores obtained by the control group (traditional methodology) during the application of the teaching unit in the variables related to the attitudinal dimension and the Mathematical dimension. In general, the scores obtained by the students of the control group are very low. Of the twelve variables analyzed, no variable exceeded the central score $(M \geq 2.5)$. The variable with the highest score in the traditional methodology has been the use of time in the classroom, the ability to solve problems, and the marks obtained in the exam, despite being very low scores. The motivation of the students and the analysis/representation of graphs has reached very low values.

Table 2. Results obtained for the study variables in the control group.

\begin{tabular}{|c|c|c|c|c|c|c|c|c|c|}
\hline & & \multicolumn{4}{|c|}{ Likert Scale $n(\%)$} & \multicolumn{4}{|c|}{ Parameters } \\
\hline & & None & Few & Enough & Completely & $\mathbf{M}$ & SD & Skew & Kurt \\
\hline \multirow{7}{*}{ 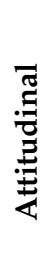 } & Motivation & $14(46.7)$ & $11(36.7)$ & $3(10)$ & $2(6.7)$ & 1.77 & 0.88 & 0.87 & 0.38 \\
\hline & Autonomy & $9(30)$ & $12(40)$ & $7(23.3)$ & $2(6.7)$ & 2.07 & 0.89 & 1.2 & -0.63 \\
\hline & Collaboration & $7(23.3)$ & $11(36.7)$ & $8(26.7)$ & 4 (13.3) & 2.3 & 0.97 & 1.34 & -0.92 \\
\hline & Participation & $10(33.3)$ & $12(40)$ & $6(20)$ & $2(6.7)$ & 2 & 0.89 & 1.12 & -0.5 \\
\hline & Resolution & $7(23.3)$ & $9(30)$ & $11(36.7)$ & $3(10)$ & 2.33 & 0.94 & 1.41 & -0.99 \\
\hline & Class time & $5(16.7)$ & $13(43.3)$ & $8(26.7)$ & $4(13.3)$ & 2.37 & 0.91 & 1.5 & -0.72 \\
\hline & Total & $52(28.9)$ & $68(37.8)$ & $43(23.9)$ & $17(9.4)$ & 2.14 & 0.94 & 1.21 & -0.77 \\
\hline \multirow{7}{*}{ 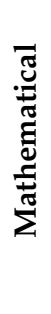 } & Concepts & $8(26.7)$ & $13(43.3)$ & $7(23.3)$ & $2(6.7)$ & 2.1 & 0.87 & 1.26 & -0.53 \\
\hline & $\begin{array}{l}\text { Scientific } \\
\text { data }\end{array}$ & $11(36.7)$ & $11(36.7)$ & $5(16.7)$ & $3(10)$ & 2 & 0.97 & 1.04 & -0.55 \\
\hline & Graphics & $12(40)$ & $12(40)$ & $4(13.3)$ & $2(6.7)$ & 1.87 & 0.88 & 0.98 & -0.01 \\
\hline & Results & $6(20)$ & $14(46.7)$ & $8(26.7)$ & $2(6.7)$ & 2.2 & 0.83 & 1.44 & -0.45 \\
\hline & Decision & $6(20)$ & $12(40)$ & $9(30)$ & $3(10)$ & 2.3 & 0.9 & 1.44 & -0.74 \\
\hline & Ratings * & $5(16.7)$ & $12(40)$ & $10(33.3)$ & $3(10)$ & 2.37 & 0.87 & 1.56 & -0.69 \\
\hline & Total & $48(26.7)$ & 74 (41.1) & 43 (23.9) & $15(8.3)$ & 2.14 & 0.91 & 1.26 & -0.65 \\
\hline
\end{tabular}

The sample grouping of "Ratings" (min: 0; max: 10) has been carried out based on the following criteria: 0-4.9: None; 5-5.9: Few; 6-8.9: Enough; 9-10: Completely. Source: Own elaboration.

\subsection{Descriptive Analysis of the Effect of Flipped Learning on the Attitudinal and Mathematical Dimension}

The results in Table 3 contain the scores obtained by the experimental group (flipped learning) during the application of the teaching unit. The scores obtained by this group reflect an optimal effectiveness of inverted learning. Of the twelve variables analyzed, the use of flipped learning allowed them to exceed the central score $(M \geq 2.5)$ for eleven of the variables. The motivation of the students and analysis and representation of graphs are the most potent variables, although the other variables also have high scores. Knowledge of scientific language and mathematical concepts is the variable with the lowest score, but it is very close to the central score $(M=2.47)$. 
Table 3. Results obtained for the study variables in the experimental group.

\begin{tabular}{|c|c|c|c|c|c|c|c|c|c|}
\hline & & \multicolumn{4}{|c|}{ Likert Scale $n(\%)$} & \multicolumn{4}{|c|}{ Parameters } \\
\hline & & None & Few & Enough & Completely & $\mathbf{M}$ & SD & Skew & Kurt \\
\hline \multirow{7}{*}{ 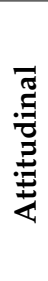 } & Motivation & $2(6.7)$ & $6(20)$ & $10(33.3)$ & $12(40)$ & 3.07 & 0.93 & 2.23 & -0.61 \\
\hline & Autonomy & $2(6.7)$ & $8(26.7)$ & $11(36.7)$ & $9(30)$ & 2.9 & 0.91 & 2.09 & -0.81 \\
\hline & Collaboration & $2(6.7)$ & $9(30)$ & $12(40)$ & $7(23.3)$ & 2.8 & 0.87 & 2.06 & -0.74 \\
\hline & Participation & $3(10)$ & $7(23.3)$ & $12(40)$ & $8(26.7)$ & 2.83 & 0.93 & 1.96 & -0.72 \\
\hline & Resolution & $5(16.7)$ & $9(30)$ & $11(36.7)$ & $5(16.7)$ & 2.53 & 0.96 & 1.6 & -0.93 \\
\hline & Class time & $4(13.3)$ & $7(23.3)$ & $11(36.7)$ & $8(26.7)$ & 2.77 & 0.99 & 1.79 & -0.92 \\
\hline & Total & $18(10)$ & $46(25.6)$ & $67(37.2)$ & 49 (27.2) & 2.82 & 0.95 & 1.92 & -0.83 \\
\hline \multirow{7}{*}{ 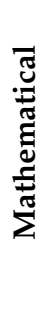 } & Concepts & $6(20)$ & $9(30)$ & $10(33.3)$ & $5(16.7)$ & 2.47 & 0.99 & 1.48 & -1.04 \\
\hline & $\begin{array}{l}\text { Scientific } \\
\text { data }\end{array}$ & $4(13.3)$ & $5(16.7)$ & $11(36.7)$ & $10(3.3)$ & 2.9 & 1.01 & 1.88 & -0.77 \\
\hline & Graphics & $3(10)$ & $4(13.3)$ & $11(36.7)$ & $12(40)$ & 3.07 & 0.96 & 2.14 & -0.33 \\
\hline & Results & $3(10)$ & $9(30)$ & $12(40)$ & $6(20)$ & 2.7 & 0.9 & 1.89 & -0.74 \\
\hline & Decision & $4(13.3)$ & $6(20)$ & $11(36.7)$ & $9(30)$ & 2.83 & 1 & 1.83 & -0.86 \\
\hline & Ratings * & 4 (13.3) & $9(30)$ & $12(40)$ & 5 (16.7) & 2.6 & 0.92 & 1.75 & -0.78 \\
\hline & Total & $24(13.3)$ & $42(23.3)$ & $67(37.2)$ & $47(26.1)$ & 2.76 & 0.99 & 1.79 & -0.9 \\
\hline
\end{tabular}

The sample grouping of "Ratings" (min: 0; max: 10) has been carried out based on the following criteria: 0-4.9:

None; 5-5.9: Few; 6-8.9: Enough; 9-10: Completely. Source: Own elaboration.

\subsection{Graphical Analysis of the Average Scores Obtained between Groups}

On the other hand, in Figure 1, a comparison between the groups is observed by means of a graph based on the average scores obtained in the Attitudinal dimension. The average scores obtained by the students of the experimental group (flipped learning) are higher than that of the students of the control group (traditional methodology), especially in the variables related to motivation in the classroom and participation in the teaching and learning process.
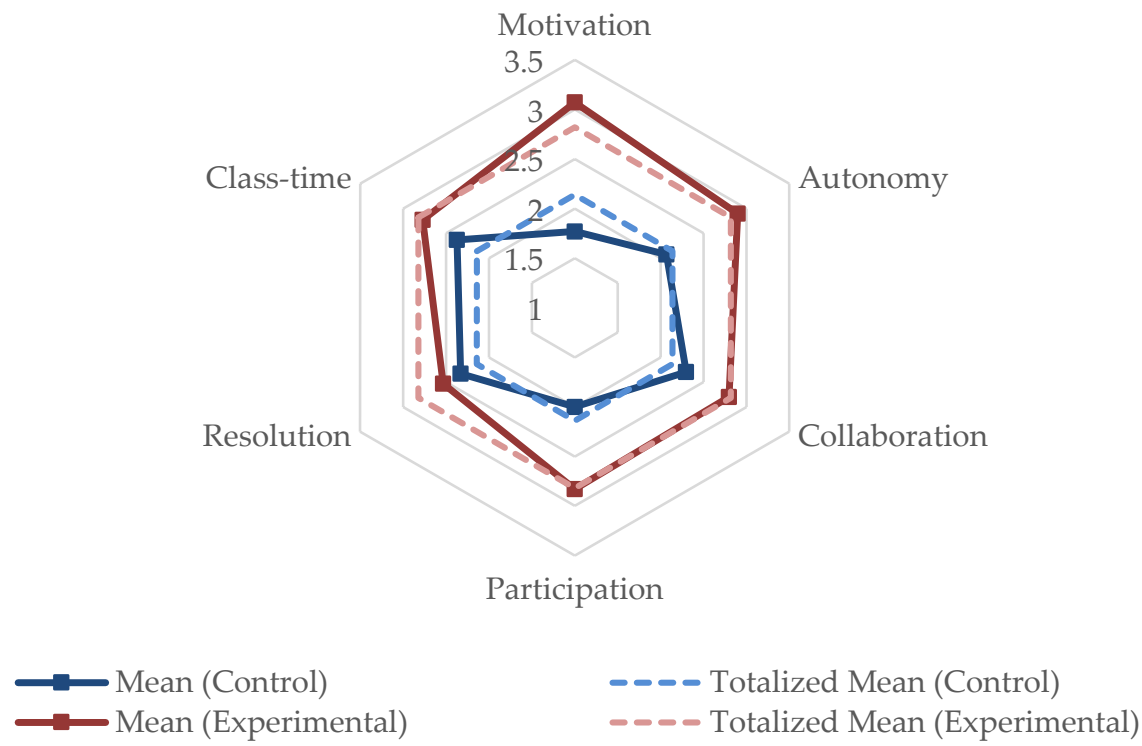

Figure 1. Intergroup comparison in the Attitudinal dimension.

Likewise, Figure 2 shows a comparison of the average scores obtained by the experimental and control group regarding the Mathematics dimension. Similar to the previous dimension, the means obtained in the Mathematical dimension by the group of flipped learning students is higher than the scores of the students of traditional methodology. The greatest differences are in the scores of the variables related to the analysis and representation of graphs, the use of data and scientific processes, and the interpretation and reflection of results. 

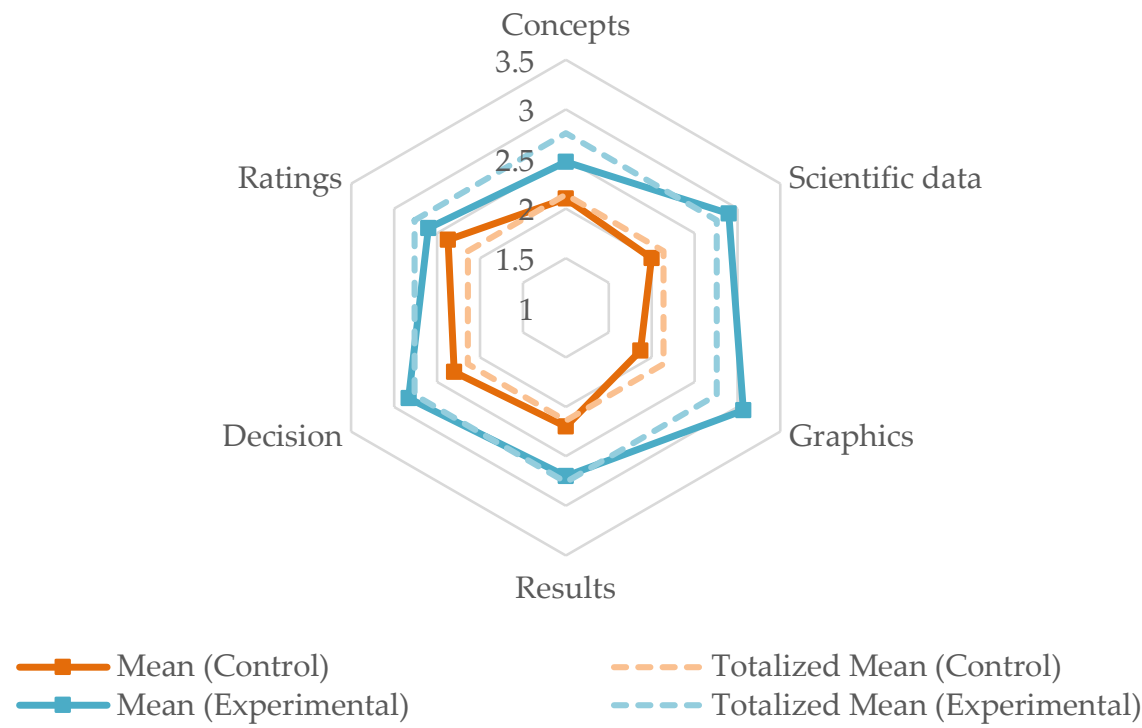

Figure 2. Intergroup comparative in the Mathematical dimension.

\subsection{Comparative Analysis of the Effect Caused by the Instructional Modality in the Study Groups}

Student's t-test was carried out (Table 4) to determine the value of independence between the results obtained during the application of the traditional approach and the flipped learning. As a corrective element for $d$ (correlation force), a distinction for biserial correlation $(r=[0,1])$ was made between a small $(r=-0.1)$, medium $(r=-0.3)$, and large $(r=-0.5)$ effect size. Likewise, it was considered a standardized value of $p<0.05$ as a statistically significant difference.

Table 4. Study of the value of independence between the control groups and experimental groups.

\begin{tabular}{|c|c|c|c|c|c|c|c|c|}
\hline & & \multicolumn{2}{|c|}{ Group, M (SD) } & \multirow{2}{*}{$\mathbf{M}_{1}-\mathbf{M}_{2}$} & \multicolumn{2}{|c|}{ Student's $t$} & \multirow{2}{*}{$d$} & \multirow{2}{*}{$r$} \\
\hline & & Control & Experimental & & $t(\mathrm{df})$ & $p$-Value & & \\
\hline \multirow{7}{*}{ 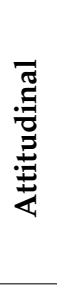 } & Motivation & $1.77(0.88)$ & $3.07(0.93)$ & -1.3 & $4.85(58)$ & $<0.001$ & -1.456 & -0.583 \\
\hline & Autonomy & $2.07(0.89)$ & $2.9(0.91)$ & -0.83 & $3.53(58)$ & $<0.001$ & -0.922 & -0.419 \\
\hline & Collaboration & $2.3(0.97)$ & $2.8(0.87)$ & -0.5 & $2.06(58)$ & 0.044 & -0.543 & -0.262 \\
\hline & Participation & $2(0.89)$ & $2.83(0.93)$ & -0.83 & $3.47(58)$ & 0.001 & -0.912 & -0.415 \\
\hline & Resolution & $2.33(0.94)$ & $2.53(0.96)$ & -0.2 & $0.8(58)$ & 0.426 & - & - \\
\hline & Class time & $2.37(0.91)$ & $2.77(0.99)$ & -0.4 & $1.6(58)$ & 0.115 & - & - \\
\hline & Total & $2.14(0.94)$ & $2.82(0.95)$ & -0.68 & $2.67(58)$ & 0.009 & -0.719 & -0.338 \\
\hline \multirow{7}{*}{ 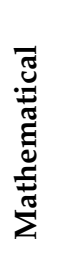 } & Concepts & $2.1(0.87)$ & $2.47(0.99)$ & -0.37 & $1.5(58)$ & 0.139 & - & - \\
\hline & Scientific data & $2(0.97)$ & $2.9(1.01)$ & -0.9 & $3.46(58)$ & 0.001 & -0.909 & -0.413 \\
\hline & Graphics & $1.87(0.88)$ & $3.07(0.96)$ & -1.2 & $4.94(58)$ & $<0.001$ & -1.303 & -0.546 \\
\hline & Results & $2.2(0.83)$ & $2.7(0.9)$ & -0.5 & $2.2(58)$ & 0.032 & -0.578 & -0.277 \\
\hline & Decision & $2.3(0.9)$ & $2.83(1)$ & -0.53 & $2.13(58)$ & 0.037 & -0.557 & -0.268 \\
\hline & Ratings * & $2.37(0.87)$ & $2.6(0.92)$ & -0.23 & $0.99(58)$ & 0.325 & - & - \\
\hline & Total & $2.14(0.91)$ & $2.76(0.99)$ & -0.62 & $2.37(58)$ & 0.021 & 0.652 & -0.309 \\
\hline
\end{tabular}

The sample grouping of "Ratings" (min: 0; max: 10) has been carried out based on the following criteria: 0-4.9: None; 5-5.9: Few; 6-8.9: Enough; 9-10: Completely. Source: Own elaboration.

It has been proven that the application of the flipped learning approach in the subject of Mathematics causes a significant improvement in several variables. The variables related to student motivation and the analysis and representation of graphs stand out above the rest. Both variables have a high association strength $(r=-0.58 ; r=-0.55$, respectively). Statistical significance has also been obtained in the variables related to student autonomy $(r=-0.42)$, participation in the learning process $(r=-0.41)$, and the use of data and scientific processes $(r=-0.41)$, obtaining a medium-low association force. Finally, it highlights the collaboration with classmates $(r=-0.26)$, interpretation and 
reflection of results $(r=-0.28)$, and decision-making by students $(r=-0.27)$ as significant variables, but with little association force. Consequently, both the Attitudinal dimension and the Mathematical dimension have obtained statistical significance, although with a medium-low association force $(r=-0.34 ; r=-0.31$, respectively).

\section{Discussion}

The projection that contemporary society has experienced as a result of the continuous advances in resources, means, and technological infrastructures [86] must be exported to the educational field with the purpose of improving the instructional actions that take out in the learning spaces [1]. Innovation must be approached from a pedagogical point of view, not only as a means, but as a technopedagogical resource to achieve more efficient learning in the different subjects that articulate every educational system [87].

Educational research has verified how the use of ICT is beneficial for the teaching profession [3] and encourages the achievement of significant and constructivist learning in students [4]. Recent literature on this state of the art states that educational technology acquires great value in the teaching and learning processes because of the potential it reaches [88-91]. In this sense, the use of innovative resources implies a substantial improvement of various academic variables concerning the attitude and performance of students [2].

These positive findings should serve to raise awareness among teachers about the importance of incorporating ICT in classrooms [44,45]. This precept has been the trigger that has driven the development of this research work. This study has helped to continue the research path of previous works published in impact databases [57-64]. These cited studies reveal the benefits and advantages of the use of flipped learning in Mathematics compared to more traditional teaching methods that have been taking place in this subject since the beginning of time.

The launch of this research has confirmed the supremacy of the innovative approach known as flipped learning compared to a traditional pedagogical action in Mathematics in the Secondary Education stage, as demonstrated in previous studies $[49,50,55,56]$. Specifically, in this study, attitudinal variables such as motivation, autonomy, collaboration, participation, problem solving, and class time have been analyzed, and specific variables related to the subject itself, such as knowledge of scientific language and mathematical concepts, the use of scientific data and processes, the analysis and representation of graphs, the interpretation and reflection of results, and appropriate decision-making in addition to the incidence of all of them in student grades.

In previous research, the use of flipped learning has resulted in obtaining positive results in the different variables presented above. By contrast, we observe that the findings have been achieved through traditional formative action, as has happened in this study. In particular, all attitudinal academic indicators such as motivation $[40,41,53,54,57]$, autonomy $[22,23,37,38,52,58]$, collaboration $[28,29,31-$ $33,60]$, participation $[34,62-64]$, problem solving [24,25,35,36], and class time [30,59] have presented analogy with other reported studies of scientific literature, as reflected.

In the same way, all mathematical variables have been successful in the pedagogical context, except for the one concerning the knowledge of scientific language and mathematical concepts. This allows us to clarify the potential that flipped learning presents in the teaching of Mathematics. All the produced improvements are directly related to student performance and grades. These have obtained good results in the evaluation tests. However, no statistical significance has been achieved in the qualifications obtained in both methodologies. Therefore, this study cannot reveal an improvement in grades as a result of the application of flipped learning, as has been reflected in previous studies [42,43].

\section{Conclusions}

Flipped learning in the teaching and learning of Mathematics in Secondary Education has proven to be an effective technopedagogical approach, both in attitudinally and in the specific subject matter. Specifically, the motivation of students and the analysis and representation of graphics have been the 
variables with the greatest projection. The comparison between the groups at the attitudinal level has allowed us to determine that the motivation and participation of the students are the most prominent indicators with flipped learning. At the specific level of Mathematics, the analysis and representation of graphs, the use of scientific data and processes, and the interpretation and reflection of results are the variables most potentiated by the innovative methodology.

The analysis of independence performed between the study groups has obtained different levels for the strength of association. The motivation and the analysis and representation of graphs present a great strength of association. These are followed by autonomy, participation, and the use of data and scientific processes with the force of central association, and the variables with lower strength of association are collaboration, interpretation and reflection of the results, and decision-making. After the results were obtained, the research questions have been answered, leaving all—except $R Q_{2}$ and $\mathrm{RQ}_{7}$ - answered affirmatively. Therefore, it is concluded that the process of teaching and learning Mathematics through flipped learning turns out to be more effective, beneficial, and potentiated than a traditional approach without any use of ICT.

The presented findings favor the projection and use of flipped learning as an effective methodology against the use of traditional pedagogical actions in the subject of Mathematics. The prospective applications of this study are based on the promotion and inclusion of innovative methodologies such as flipped learning in learning spaces, with the purpose of adapting current teaching to an increasingly technological society.

Finally, the level of digital competence of teachers who used flipped learning to impart the contents was the most prominent limitation of the study. On another point, the sample size may be another limitation but for this type of study, it is considered acceptable as justified above, backed by impact studies. However, the small size of each subgroup was determined by the number of students that make up each classroom analyzed in the school. Although, due to the sample size, the results cannot be generalized to the entire population of students, and this study finds its value in the establishment of a starting point and in the opening of an exploratory window that serves to mark the direction of future related research with the effectiveness of flipped learning in Mathematics. As a future line of research, we intend to analyze the influence of digital teaching competence on student performance following a flipped learning approach.

Supplementary Materials: The following are available online at http://www.mdpi.com/2227-7390/7/12/1226/s1, Table S1: Questionnaire CONEXP014FLM.

Author Contributions: Conceptualization, J.L.B., A.F.C. and J.A.L.N.; methodology, J.L.B. and S.P.S.; software, S.P.S; validation, S.P.S. and J.A.L.N.; formal analysis, J.L.B. and J.A.L.N.; investigation, J.L.B., A.F.C., J.A.L.N. and S.P.S.; data curation, S.P.S.; writing—original draft preparation, J.L.B. and A.F.C.; writing-review and editing, J.L.B. and S.P.S.; visualization, A.F.C.; supervision, J.A.L.N. and A.F.C.

Funding: This research received no external funding.

Acknowledgments: We acknowledge the researchers of the research group AREA (HUM-672), which belongs to the Ministry of Education and Science of the Junta de Andalucía and registered in the Department of Didactics and School Organization of the Faculty of Education Sciences of the University of Granada.

Conflicts of Interest: The authors declare no conflict of interest.

\section{References}

1. Area, M.; Hernández, V.; Sosa, J.J. Modelos de integración didáctica de las TIC en el aula. Comunicar 2016, 24, 79-87. (In Spanish) [CrossRef]

2. Pereira, S.; Fillol, J.; Moura, P. El aprendizaje de los jóvenes con medios digitales fuera de la escuela: De lo informal a lo formal. Comunicar 2019, 1, 41-50. (In Spanish) [CrossRef]

3. Li, S.; Yamaguchi, S.; Sukhbaatar, J.; Takada, J. The Influence of Teachers' Professional Development Activities on the Factors Promoting ICT Integration in Primary Schools in Mongolia. Educ. Sci. 2019, 9, 78. [CrossRef]

4. Garrote, D.; Arenas, J.A.; Jiménez-Fernández, S. ICT as tools for the development of intercultural competence. EDMETIC 2018, 7, 166-183. [CrossRef] 
5. Llanos, G.; Bravo, J. Flipped classroom como Puente hacia nuevos retos en la educación primaria. Rev. Tecno. Cien. Edu. 2017, 8, 39-49. Available online: https://www.tecnologia-ciencia-educacion.com/judima/index. php/TCE/article/view/153/125 (accessed on 10 October 2019).

6. Sánchez, E.; Sánchez, J.; Ruiz, J. Percepción del alumnado universitario respecto al modelo pedagógico de clase invertida. Magis 2019, 11, 151-168. (In Spanish) [CrossRef]

7. López, J.; Pozo, S.; del Pino, M.J. Projection of the Flipped Learning Methodology in the Teaching Staff of Cross-Border Contexts. NAER 2019, 8, 184-200. [CrossRef]

8. Froehlich, D.E. Non-technological learning environments in a technological world: Flipping comes to the aid. NAER 2018, 7, 94-99. [CrossRef]

9. McLaughlin, J.E.; Roth, M.T.; Glatt, D.M.; Gharkholonarehe, N.; Davidson, C.A.; Griffin, L.M.; Esserman, D.; Mumper, R.J. The flipped classroom: a course redesign to foster learning and engagement in a health professions school. Acad. Med. 2014, 89, 236-243. [CrossRef]

10. Seery, M.K. Flipped learning in higher education chemistry: emerging trends and potential directions. Chem. Educ. Res. Pract. 2015, 16, 758-768. [CrossRef]

11. Zainuddin, Z.; Habiburrahim, H.; Muluk, S.; Keumala, C.M. How do students become self-directed learners in the EFL flipped-class pedagogy? A study in higher education. Indones. J. Appl. Linguist. 2019, 8, 678-690. [CrossRef]

12. Bergmann, J.; Sams, A. Flip Your Classroom: Reach Every Student in Every Class Every Day, 1st ed.; ISTE: Washington, DC, USA, 2012; pp. 34-40.

13. Sola, T.; Aznar, I.; Romero, J.M.; Rodríguez, A.M. Eficacia del método flipped classroom en la universidad: Meta-análisis de la producción científica de impacto. REICE 2019, 17, 25-38. (In Spanish) [CrossRef]

14. Awidi, I.T.; Paynter, M. The impact of a flipped classroom approach on student learning experience. Comput. Educ. 2019, 128, 269-283. [CrossRef]

15. Nortvig, A.M.; Petersen, A.K.; Hattesen, S. A Literature Review of the Factors Influencing E-Learning and Blended Learning in Relation to Learning Outcome, Student Satisfaction and Engagement. Electro. J. E-Learn. 2018, 16, 46-55. Available online: https://bit.ly/2W4iMHL (accessed on 10 October 2019).

16. Yoshida, H. Perceived usefulness of "flipped learning" on instructional design for elementary and secondary education: With focus on pre-service teacher education. Int. J. Inf. Educ. Technol. 2016, 6, 430-434. [CrossRef]

17. Lee, J.; Lim, C.; Kim, H. Development of an instructional design model for flipped learning in higher education. Educ. Technol. Res. Develop. 2017, 65, 427-453. [CrossRef]

18. Jensen, J.L.; Holt, E.A.; Sowards, J.B.; Ogden, T.H.; West, R.E. Investigating strategies for pre-class content learning in a flipped classroom. J. Sci. Educ. Technol. 2018, 27, 523-535. [CrossRef]

19. Kwan, C.; Foon, K. A critical review of flipped classroom challenges in K-12 education: possible solutions and recommendations for future research. Res. Pract. Technol. Enhan. Learn. 2017, 12, 1-22. [CrossRef]

20. Bauer, C.; Graney, J.M.; Marshall, H.W.; Sabieh, C. Flipped learning in TESOL: Definitions, approaches, and implementation. Tesol J. 2016, 7, 429-437. [CrossRef]

21. López, J.; Pozo, S.; Fuentes, A.; López, J.A. Creación de contenidos y flipped learning: un binomio necesario para la educación del nuevo milenio. REP 2019, 77, 535-555. (In Spanish) [CrossRef]

22. Abeysekera, L.; Dawson, P. Motivation and cognitive load in the flipped classroom: definition, rationale and a call for research. High. Educ. Res. Develop. 2015, 34, 1-26. [CrossRef]

23. Barao, L.; Palau, R.F. Análisis de la implementación de Flipped Classroom en las asignaturas instrumentales de $4^{\circ}$ Educación Secundaria Obligatoria. Edutec 2016, 1, 1-13. (In Spanish) [CrossRef]

24. Long, T.; Cummins, J.; Waugh, M. Use of the flipped classroom instructional model in higher education: instructors' perspectives. J. Comput. High. Educ. 2017, 29, 179-200. [CrossRef]

25. Schmidt, S.M.; Ralph, D.L. The Flipped Classroom: A Twist on Teaching. Contemp. Issues Educ. Res. 2016, 9 , 1-6. [CrossRef]

26. El Miedany, Y. Flipped learning. In The flipped classroom: Practice and practices in higher education, 1st ed.; Reidsema, C., Kavanagh, L., Hadgraft, R., Smith, N., Eds.; Springer: New York, NY, USA, 2019; Volume 1, pp. 285-303. [CrossRef]

27. Khadri, H.O. Flipped learning as a new educational paradigm: An analytical critical study. Eur. Sci. J. 2016, 12, 417-444. [CrossRef]

28. Nouri, J. The flipped classroom: for active, effective and increased learning-especially for low achievers. Int. J. Educ. Technol. High. Educ. 2016, 13, 1-10. [CrossRef] 
29. Zainuddin, Z.; Halili, S.H. Flipped classroom research and trends from different fields of study. Int. Rev. Res. Open Distrib. Learn. 2016, 17, 313-340. [CrossRef]

30. Mengual, S.; López, J.; Fuentes, A.; Pozo, S. Modelo estructural de factores extrínsecos influyentes en el flipped learning. Educ. XX1 2019, 23, 75-101. (In Spanish) [CrossRef]

31. Báez, C.I.; Clunie, C.E. Una mirada a la Educación Ubicua. RIED 2019, 22, 325-344. (In Spanish) [CrossRef]

32. Castellanos, A.; Sánchez, C.; Calderero, J.F. Nuevos modelos tecnopedagógicos. Competencia digital de los alumnos universitarios. REDIE 2017, 19, 1-9. (In Spanish) [CrossRef]

33. Hwang, G.J.; Lai, C.L.; Wang, S.Y. Seamless flipped learning: a mobile technology-enhanced flipped classroom with effective learning strategies. J. Comput. Educ. 2015, 2, 449-473. [CrossRef]

34. Chyr, W.L.; Shen, P.D.; Chiang, Y.C.; Lin, J.B.; Tsia, C.W. Exploring the effects of online academic help-seeking and flipped learning on improving students' learning. J. Educ. Technol. Soc. 2017, 20, 11-23. Available online: https://bit.ly/35RTgeS (accessed on 10 October 2019).

35. Bognar, B.; Sablić, M.; Škugor, A. Flipped learning and Online Discussion in Higher Education Teaching. In The flipped classroom: Practice and practices in higher education, 1st ed.; Reidsema, C., Kavanagh, L., Hadgraft, R., Smith, N., Eds.; Springer: New York, NY, USA, 2019; Volume 1, pp. 371-392. [CrossRef]

36. Long, T.; Logan, J.; Waugh, M. Students' perceptions of the value of using videos as a pre-class learning experience in the flipped classroom. TechTrends 2016, 60, 245-252. [CrossRef]

37. Salas, R.A.; Lugo, J.L. Impacto del aula invertida durante el proceso educativo superior sobre las derivadas con- siderando la ciencia de datos y el aprendizaje automático. EDMETIC 2019, 8, 147-170. (In Spanish) [CrossRef]

38. Tourón, J.; Santiago, R. El modelo Flipped learning y el desarrollo del talento en la escuela. Rev. De Educ. 2015, 1, 196-231. (In Spanish) [CrossRef]

39. Boelens, R.; Voet, M.; De Wever, B. The design of blended learning in response to student diversity in higher education: Instructors' views and use of differentiated instruction in blended learning. Comput. Educ. 2018, 120, 197-212. [CrossRef]

40. Shih, W.L.; Tsai, C.Y. Students' perception of a flipped classroom approach to facilitating online project-based learning in marketing research courses. Australas. J. Educ. Technol. 2017, 33, 32-49. [CrossRef]

41. Tse, W.S.; Choi, L.Y.; Tang, W.S. Effects of video-based flipped class instruction on subject reading motivation. Br. J. Educ. Technol. 2019, 50, 385-398. [CrossRef]

42. Fisher, R.; Ross, B.; LaFerriere, R.; Maritz, A. Flipped learning, flipped satisfaction, getting the balance right. Teach. Learn. Inq. 2017, 5, 114-127. [CrossRef]

43. Karabulut, A.; Jaramillo, N.; Hassall, L. Flipping to engage students: Instructor perspectives on flipping large enrolment courses. Australas. J. Educ. Technol. 2018, 34, 123-137. [CrossRef]

44. Nikolopoulou, K.; Akriotou, D.; Gialamas, V. Early Reading Skills in English as a Foreign Language Via ICT in Greece: Early Childhood Student Teachers' Perceptions. Early Child. Educ. J. 2019, 47, 597-606. [CrossRef]

45. Escobar, J.C.; Sánchez, P.A. Limitaciones conceptuales para la evaluación de la competencia digital. Espacios 2018, 39, 1-11.

46. Nogueira, F.; Shigueo, E.; Abdala, H. Collaborative Teaching and Learning Strategies for Communication Networks. Int. J. Engi. Educ. 2018, 34, 527-536.

47. Cabero, J.; Barroso, J. Los escenarios tecnológicos en Realidad Aumentada (RA): posibilidades educativas en estudios universitarios. Aula Abierta 2018, 47, 327-336. (In Spanish) [CrossRef]

48. Cuevas, R.E.; Feliciano, A.; Alarcón, A.; Catalán, A.; Alonso, G.A. The integration of ICT tools to the profile of the Computer Engineer of the Autonomous University of Guerrero, Mexico. Virtualidad Educ. Y Cienc. 2019, 10, 20-32.

49. Huan, C. A Study on Digital Media Technology Courses Teaching Based on Flipped Classroom. Am. J. Educ. Res. 2016, 4, 264-267. [CrossRef]

50. Thai, N.T.; De Wever, B.; Valcke, M. The impact of a flipped classroom design on learning performance in higher education: Looking for the best "blend" of lectures and guiding questions with feedback. Comput. Educ. 2017, 107, 113-126. [CrossRef]

51. Hodges, T.; Conner, E. Reflections on a Technology-Rich Mathematics Classroom. Math. Teach. 2011, 104, 432-438. Available online: https://www.learntechlib.org/p/52924/ (accessed on 10 October 2019). 
52. Cruz, I.M.; Puentes, A. Innovación educativa: Uso de las TIC en la enseñanza de la Matemática básica. EDMETIC 2012, 1, 127-145. Available online: https://www.uco.es/ucopress/ojs/index.php/edmetic/article/ viewFile/2855/2744 (accessed on 10 October 2019). (In Spanish). [CrossRef]

53. De Araujo, Z.; Otten, S.; Birisci, S. Conceptualizing "homework" in flipped mathematics classes. J. Educ. Technol. Soc. 2017, 20, 248-260. Available online: https://www.jstor.org/stable/jeductechsoci.20.1.248 (accessed on 10 October 2019).

54. Bishop, J.L.; Verleger, M.A. The flipped classroom: A survey of the research. In Proceedings of the ASEE National Conference, Atlanta, GA, USA, 23-26 June 2013.

55. McGivney-Burelle, J.; Xue, F. Flipping Calculus. PRIMUS 2013, 23, 477-486. [CrossRef]

56. Talbert, R. Inverting the Linear Algebra classroom. PRIMUS 2014, 24, 361-374. [CrossRef]

57. Love, B.; Hodge, A.; Grandgenett, N.; Swift, A.W. Student learning and perceptions in a flipped linear algebra course. Int. J. Math. Educ. Sci. Technol. 2014, 45, 317-324. [CrossRef]

58. Lai, C.L.; Hwang, G.J. A self-regulated flipped classroom approach to improving students' learning performance in a mathematics course. Comput. Educ. 2016, 100, 126-140. [CrossRef]

59. Lo, C.K.; Hew, K.F.; Chen, G. Toward a set of design principles for mathematics flipped classrooms: A synthesis of research in mathematics education. Educ. Res. Rev. 2017, 22, 50-73. [CrossRef]

60. Lopes, A.P.; Soares, F. Perception and performance in a flipped Financial Mathematics classroom. Int. J. Manag. Educ. 2018, 16, 105-113. [CrossRef]

61. Muir, T.; Geiger, V. The affordances of using a flipped classroom approach in the teaching of mathematics: a case study of a grade 10 mathematics class. Math. Educ. Res. J. 2016, 28, 149-171. [CrossRef]

62. Adams, C.; Dove, A. Calculus students flipped out: The impact of flipped learning on calculus students achievement and perceptions of learning. PRIMUS 2018, 28, 600-615. [CrossRef]

63. Amstelveen, R. Flipping a college mathematics classroom: An action research project. Educ. Inf. Technol. 2019, 24, 1337-1350. [CrossRef]

64. Sun, Z.; Xie, K.; Anderman, L.H. The role of self-regulated learning in students' success in flipped undergraduate math courses. Inter. High. Educ. 2018, 36, 41-53. [CrossRef]

65. Contreras, M. La competencia matemática con la calculadora Classpad330. Epsilon. Rev. De Educ. Matemática 2010, 76, 9-32. (In Spanish)

66. Hernández, J.L. GeoGebra, un cambio radical en el entorno del aprendizaje. Epsilon. Rev. De Educ. Matemática 2010, 74, 53-65. (In Spanish)

67. Freeman, S.; Eddy, S.; McDonough, M.; Smith, M.; Okoroafor, N.; Jordt, H.; Wenderoth, M.P. Active learning increases student performance in science, engineering, and mathematics. Proc. Natl. Acad. Sci. 2014, 111, 8410-8415. [CrossRef] [PubMed]

68. Hwang, G.J.; Lai, C.L. Facilitating and bridging out-of-class and in-class learning: An interactive e-book-based flipped learning approach for math courses. Educ. Technol. Soc. 2017, 20, 184-197.

69. Jordán, C.; Pérez-Peñalver, M.J.; Sanabria, E. Investigación del impacto en un aula de matemáticas al utilizar flip education. Pensam. Matemático 2014, 4, 9-22. (In Spanish)

70. Cabus, S.J.; Haelermans, C.; Franken, S. SMART in Mathematics? Exploring the effects of in-class-level differentiation using SMARTboard on math proficiency. Br. J. Educ. Technol. 2017, 48, 145-161. [CrossRef]

71. Nicholas, K.; Fletcher, J. What is happening in the use of ICT mathematics to support young adolescent learners? A New Zealand experience. Educ. Rev. 2017, 69, 474-489. [CrossRef]

72. Larionova, V.; Brown, K.; Bystrova, T.; Sinitsyn, E. Russian perspectives of online learning technologies in higher education: An empirical study of a MOOC. Res. Compar. Int. Educ. 2018, 13, 70-91. [CrossRef]

73. He, W.; Holton, A.; Farkas, G.; Warschauer, M. The effects of flipped instruction on out-of-class study time, exam performance, and student perceptions. Learn. Instr. 2016, 45, 61-71. (In Spanish). [CrossRef]

74. Santiago, R.; Bergmann, J. Aprender al revés, 1st ed.; Paidós Educación: Barcelona, Spain, 2018; pp. $133-142$.

75. Hinojo, F.J.; Aznar, I.; Romero, J.M.; Marín, J.A. Influencia del aula invertida en el rendimiento académico. Una revisión sistemática. Campus Virtuales 2019, 8, 9-18. Available online: https://bit.ly/2MP6Arz (accessed on 10 October 2019). (In Spanish).

76. Fernández, M.; Espada, M. Formación inicial y percepción del profesorado sobre los estilos de enseñanza en Educación Física. Retos 2017, 1, 69-75. (In Spanish)

77. Pérez, A. Uso de smartphones y redes sociales en alumnos/as de educación primaria. Prism. Soc. 2018, 1, 76-91. (In Spanish) 
78. Hernández, R.; Fernández, C.; Baptista, M.P. Metodología de la investigación, 6th ed.; McGraw Hill: Madrid, Spain, 2014; pp. 129-168. (In Spanish)

79. Rodríguez, N. Diseños experimentales en educación. REP 2011, 32, 147-158. (In Spanish)

80. Chou, P.N.; Feng, S.T. Using a Tablet Computer Application to Advance High School Students' Laboratory Learning Experiences: A Focus on Electrical Engineering Education. Sustainability 2019, 11, 381. [CrossRef]

81. Yilmaz, A.; Soyer, F. Effect of Physical Education and Play Applications on School Social Behaviors of Mild-Level Intellectually Disabled Children. Educ. Sci. 2018, 8, 89. [CrossRef]

82. Amador, L.V.; Mateos, F.; Esteban, M. La educación como medio para la inclusión social entre culturas (los valores sociales de los jóvenes ceutís de cultura cristiana y musulmana). Pedagog. Soc. 2017, 1, 67-80. (In Spanish)

83. Molina, P.J. Ceuta y su relación con las amenazas emergentes. Rev. De Pens. Estra. Y Seg. 2017, 2, 9-20. (In Spanish)

84. Driscoll, T. Flipped Learning and democratic Education. Graduate Thesis, Columbia University, New York, NY, USA, 2012.

85. Martín, D.; Sáenz, M.; Santiago, R.; Chocarro, E. Diseño de un instrumento para evaluación diagnóstica de la competencia digital docente: formación flipped classroom. DIM 2016, 1, 1-15. Available online: https://bit.ly/2BlOqby (accessed on 10 October 2019). (In Spanish).

86. Maldonado, G.A.; García, J.; Sampedro-Requena, B. The effect of ICT and social networks on university students. RIED 2019, 22, 153-176. [CrossRef]

87. Urban, E.R.; Navarro, M.; Borron, A. TPACK to GPACK? The examination of the technological pedagogical content knowledge framework as a model for global integration into college of agriculture classrooms. Teach. Teach. Educ. 2018, 73, 81-89. [CrossRef]

88. Álvarez-Rodríguez, M.D.; Bellido-Márquez, M.D.; Atencia-Barrero, P. Teaching though ICT in Obligatory Secundary Education. Analysis of online teaching tools. RED 2019, 1, 1-19. [CrossRef]

89. Khine, M.S.; Ali, N.; Afari, E. Exploring relationships among TPACK constructs and ICT achievement among trainee teachers. Educ. Infor. Technol. 2017, 22, 1605-1621. [CrossRef]

90. Mat, N.S.; Abdul, A.; Mat, M.; Abdul, S.Z.; Nun, N.F.; Hamdan, A. An evaluation of content creation for personalised learning using digital ICT literacy module among aboriginal students (MLICT-OA). TOJDE 2019, 20, 41-58.

91. López-Quintero, J.L.; Pontes-Pedrajas, A.; Varo-Martínez, M. The role of ICT in Hispanic American scientific and technological education: A review of literature. Dig. Educ. Rev. 2019, 1, 229-243. 